\title{
Phosphorus burial in the ocean over glacial-interglacial time scales
}

\author{
F. Tamburini ${ }^{1, *}$ and K. B. Föllmi ${ }^{2, * *}$ \\ ${ }^{1}$ Geological Institute, D-ERDW, ETH Zürich, Zürich, Switzerland \\ ${ }^{2}$ Institut de Géologie, Université de Neuchâtel, Neuchâtel, Switzerland \\ *now at: Group of Plant Nutrition, D-AGRL, ETH Zürich, Zürich, Switzerland \\ *** now at: Institut de Géologie et Paléontologie, IGP, Université de Lausanne, Lausanne, Switzerland
}

Received: 14 October 2008 - Published in Biogeosciences Discuss.: 18 December 2008

Revised: 20 March 2009 - Accepted: 25 March 2009 - Published: 2 April 2009

\begin{abstract}
The role of nutrients, such as phosphorus (P), and their impact on primary productivity and the fluctuations in atmospheric $\mathrm{CO}_{2}$ over glacial-interglacial periods are intensely debated. Suggestions as to the importance of $\mathrm{P}$ evolved from an earlier proposal that $\mathrm{P}$ actively participated in changing productivity rates and therefore climate change, to most recent ones that changes in the glacial ocean inventory of phosphorus were important but not influential if compared to other macronutrients, such as nitrate. Using new data coming from a selection of ODP sites, we analyzed the distribution of oceanic $\mathrm{P}$ sedimentary phases and calculate reactive $\mathrm{P}$ burial fluxes, and we show how $\mathrm{P}$ burial fluxes changed over the last glacial-interglacial period at these sites. Concentrations of reactive $\mathrm{P}$ are generally lower during glacial times, while mass accumulation rates (MAR) of reactive $\mathrm{P}$ show higher variability. If we extrapolate for the analyzed sites, we may assume that in general glacial burial fluxes of reactive $\mathrm{P}$ are lower than those during interglacial periods by about $8 \%$, because the lack of burial of reactive $\mathrm{P}$ on the glacial shelf reduced in size, was apparently not compensated by burial in other regions of the ocean. Using the calculated changes in $\mathrm{P}$ burial, we evaluate their possible impact on the phosphate inventory in the world oceans. Using a simple mathematical approach, we find that these changes alone could have increased the phosphate inventory of glacial ocean waters by $17-40 \%$ compared to interglacial stages. Variations in the distribution of sedimentary $\mathrm{P}$ phases at the investigated sites seem to indicate that at the onset of interglacial stages, shallower sites experienced an increase in reactive $\mathrm{P}$ concentrations, which seems to point to P-richer waters at glacial terminations. All these findings would sup-
\end{abstract}

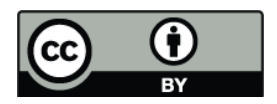

Correspondence to: F. Tamburini (federica.tamburini@ipw.agrl.ethz.ch) port the Shelf-Nutrient Hypothesis, which assumes that during glacial low stands nutrients are transferred from shallow sites to deep sea with possible feedback on the carbon cycle.

\section{Introduction}

Phosphorus $(\mathrm{P})$ is a limiting nutrient and this property closely couples the $\mathrm{P}$ cycle to that of carbon (C). Therefore, past variations in its global budget (i.e. inputs from the continent vs. output to the sediments) have been invoked as a factor influencing climate change (Van Cappellen and Ingall, 1994; Föllmi, 1996). Due to the increased availability of sediment cores and development of accurate speciation techniques (Ruttenberg, 1992; Anderson and Delaney, 2000; Schenau et al., 2000), research on the P cycle in marine environments has intensified. It is widely accepted that degradation of organic matter and early diagenetic transformations in the sediments impact the $\mathrm{P}$ cycle, since dissolved $\mathrm{P}$ may also be released back to pore and bottom waters. The degree of diagenetic redistribution and regeneration of $\mathrm{P}$ is generally dictated by local and global processes, such as organic matter deposition to the sea floor, water column ventilation, oceanic circulation, and sedimentation rates. Long-term changes in these processes should be taken into account when studying the $\mathrm{P}$ cycle over glacial-interglacial times. Estimates of $\mathrm{P}$ burial in modern oceans have been derived from several compilations for modern sediments (Baturin, 1988; Ruttenberg, 1993; Filippelli, 1997; Delaney, 1998; Tsandev et al., 2008). However, only a few studies provided estimates of $\mathrm{P}$ burial fluxes (BF) during the last glacial period (Filippelli et al., 2007), and show local records of glacial P concentrations and mass accumulation rates (MAR) (Ganeshram et al., 2002; Tamburini et al., 2003; Schenau et al., 2005; Filippelli

Published by Copernicus Publications on behalf of the European Geosciences Union. 


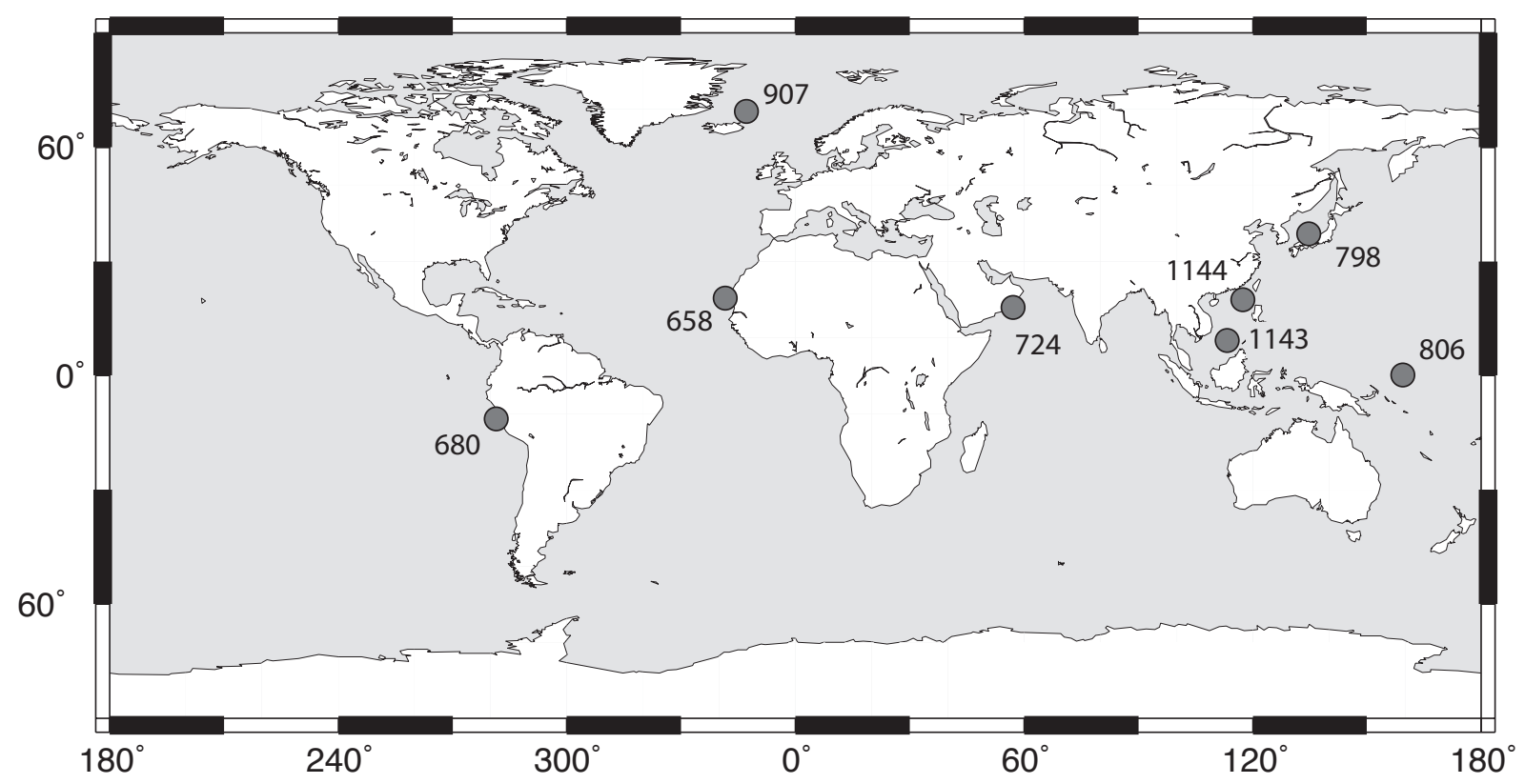

Fig. 1. World map with the investigated ODP Sites locations (see Table 1 for more information).

et al., 2007). As a consequence, all glacial reconstructions of phosphate concentrations in the ocean have been generally based on the use of other proxies, such as $\delta^{13} \mathrm{C}$ and $\mathrm{Cd} / \mathrm{Ca}$ of benthic foraminifers (Boyle and Keigwin, 1987) and on their empirical relationships with phosphate concentrations (Broecker and Peng, 1982). Here, using material from sediment cores distributed around the world oceans, we present sedimentary $\mathrm{P}$ concentrations, $\mathrm{P}$ MAR and $\mathrm{C} / \mathrm{P}$ reactive ratio data covering the last glacial-interglacial period. Following a description and discussion about the distribution and variations of $\mathrm{P}$ in the sediments, we use these data to provide a preliminary calculation on how the phosphate inventory of the ocean may have changed over glacial interglacial time scales.

\section{Materials and methods}

Eight ODP (Ocean Drilling Program) Cores were chosen from different environmental and oceanographic settings and sampled (Fig. 1 and Table 1). Depending on sediment accumulation rates, sampled intervals vary from $3 \mathrm{~m}$ (ODP Site 907) to $114 \mathrm{~m}$ (ODP Site 1144). To account for the postdepositional redistribution pattern, $\mathrm{P}$ was extracted using a modified SEDEX method (Filippelli and Delaney, 1996), which identifies four sedimentary phases containing P; i.e. three reactive phases (loosely and Fe-bound, authigenic, and organically-bound), and one unreactive detrital phase (for averages of the different $P$ phases concentrations and reactive $P$ MAR, see Table 1; for a compilation of all data, see Supplementary Material http://www.biogeosciences.net/6/501/ 2009/bg-6-501-2009-supplement.pdf). P concentrations in the different extracts were then quantified by colourimetry and by ICP-OES (Eaton et al., 1995). The original SEDEX method allows also the quantification of the loosely-bound or exchangeable $\mathrm{P}$ phase (generally $\mathrm{P}$ adsorbed on particle surfaces), which in the method used for this study is associated with Fe-bound P (Ruttenberg, 1992). This simplification was introduced because the targeted samples are ancient sediments, where concentrations of the exchangeable $\mathrm{P}$ phase are likely to be small and unimportant. In any case, the analytical approach used here allows the distinction between bioavailable (reactive $\mathrm{P}$ ) and unreactive phases, which is key to unraveling the relationship between the $\mathrm{P}$ and $\mathrm{C}$ cycles (Ruttenberg, 1992). Although the sedimentary phases recognized are operationally defined, at some sites (e.g. ODP Site 724) the comparison of the $\mathrm{P}$ phases with other mineralogical and geochemical proxies indicates that the differentiation made during the extraction is most likely a good approximation of the distribution in the sediments (Tamburini, 2002). However, this might not be true for all settings, since the distribution obtained by sequential extraction and the real one may differ (Ruttenberg, 1992). Samples were run in duplicates and the analytical errors are $4 \%$ for loosely- and Fe-bound P, $5 \%$ for authigenic $\mathrm{P}, 4 \%$ for detrital $\mathrm{P}$, and $4 \%$ for organic $\mathrm{P}$. Organic carbon was quantified on about $100 \mathrm{mg}$ of dried and ground sediment, with a Rock-Eval 6, and using a standard whole rock pyrolysis method (Espitalié et al., 1986). The method consists of a pyrolysis step (temperature at $300^{\circ} \mathrm{C}$ for 3 min then gradual increase to $650^{\circ} \mathrm{C}$ ) and an oxidation step (temperature gradient from $400^{\circ} \mathrm{C}$ to $850^{\circ} \mathrm{C}$ ). Total organic carbon is obtained as the sum of four peaks: the $\mathrm{S}_{1}$ peak (hydrocarbons released at $300^{\circ} \mathrm{C}$, FID-curve), the $\mathrm{S}_{2}$ peak 
Table 1. Marine isotopic stages (MIS), average phosphorus phases concentrations (in $\mu \mathrm{mol} / \mathrm{g}$ ), mass accumulation rates (MAR, average and range of values; in $\mu \mathrm{mol} / \mathrm{cm}^{2} / \mathrm{kyr}$ ) of reactive and detrital phosphorus from the studied ODP Sites ( $n$ is number of points on which the averages are based). ** Fe-bound P: as discussed in Material and Methods, phosphorus associated to this sedimentary phase represents both exchangeable and Fe-bound P, as they are defined in Ruttenberg (1992). ${ }^{\text {a: }}$ : Ages and sedimentation rates (SR) from Sarnthein and Tiedemann (1989). Dry bulk density (DBD) from ODP Initial Reports Vol. 108 (Ruddiman et al., 1988). ${ }^{\text {b }}$ : Ages and SR from Wefer et al. (1990). DBD from ODP Initial Reports Vol. 112 (Suess et al., 1988). c : Ages and SR from Zahn and Pedersen (1991). DBD from ODP Initial Reports Vol. 117 (Prell et al., 1989). d. Ages and SR calculated by graphic correlation of the grey scale provided in Föllmi et al. (1992) and of the

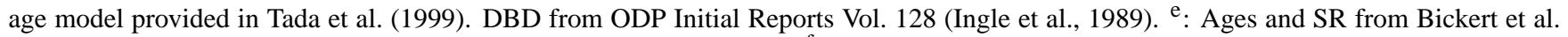
(1993). DBD from ODP Initial Reports Vol. 130 (Kroenke et al., 1991). ${ }^{\text {f: }}$. Ages and SR from McManus et al. (1996). DBD from ODP Initial Reports Vol. 151 (Myhre et al., 1995). g: Ages and SR from Tian et al. (2002). DBD from ODP Initial Reports Vol. 184 (Wang et al., 2000). h: Ages and SR from Bühring et al. (2000). DBD from ODP Initial Reports Vol. 184 (Wang et al., 2000).

\begin{tabular}{|c|c|c|c|c|c|c|c|c|}
\hline MIS & Fe-bound $\mathrm{P}$ & Authigenic P & Detrital P & Org. P & Reac. P MAR & P MAR range & Detr. P MAR & $n$ \\
\hline \multicolumn{9}{|c|}{ Site 108-658; Eastern Tropical Atlantic; mbsl (meters below sea level): 2263, continental rise ${ }^{a}$} \\
\hline 1 & 4.57 & 8.9 & 1.1 & 6.32 & 340.3 & $279-443$ & 18.92 & 4 \\
\hline 2 & 2.88 & 8.72 & 2.45 & 2.93 & 344.9 & $316-385$ & 58.16 & 5 \\
\hline 3 & 3.69 & 8.82 & 1.39 & 3.97 & 205.67 & $130-363$ & 17.35 & 4 \\
\hline 4 & I & I & I & I & I & / & I & l \\
\hline 5 & 4.99 & 9.52 & 0.9 & 3.3 & 231.14 & $156-334$ & 11.68 & 12 \\
\hline 6 & 2.19 & 9.22 & 1.58 & 1.57 & 208.09 & l & 25.33 & 1 \\
\hline IG & & & & & 247.88 & & 15.98 & \\
\hline $\mathrm{G}$ & & & & & 322.17 & & 41.74 & \\
\hline \multicolumn{9}{|c|}{ Site 112-680; Peru Continental Margin; mbsl: 252.2, upwelling, Oxygen Minimum Zone ${ }^{b}$} \\
\hline 1 & 43.48 & 44.57 & 2.93 & 9.38 & 2469.06 & 1963-2583 & 74.25 & 5 \\
\hline 2 & 75.66 & 37.87 & 3.67 & 2.8 & 1669.02 & $1291-1873$ & 52.65 & 3 \\
\hline 3 & 33.85 & 60.06 & 2.47 & 2.42 & 617.32 & 461-777 & 15.83 & 5 \\
\hline 4 & 31.65 & 78.02 & 5.12 & 2.25 & 962.98 & $722-1368$ & 44.05 & 3 \\
\hline 5 & 18 & 52.43 & 2.04 & 2.8 & 521.19 & 199-1249 & 14.52 & 9 \\
\hline 6 & 35.23 & 11.91 & 0.58 & 2.35 & 398.75 & l & 4.67 & 1 \\
\hline IG & & & & & 1059.08 & & 34.87 & \\
\hline $\mathrm{G}$ & & & & & 1184.96 & & 33.79 & \\
\hline \multicolumn{9}{|c|}{ Site 117-724; Oman Margin; mbsl: 292.8, upwelling, Oxygen Minimum Zone ${ }^{\mathrm{c}}$} \\
\hline 1 & 3.12 & 52.42 & 5.7 & 2.21 & 978.98 & $196-2142$ & 96.63 & 4 \\
\hline 2 & 1.73 & 24.09 & 6.53 & 1.28 & 459.3 & $366-542$ & 110.67 & 3 \\
\hline 3 & 1.65 & 28.65 & 7.26 & 0.92 & 356.3 & $251-439$ & 82.86 & 9 \\
\hline 4 & 1.73 & 31.27 & 6.28 & 0.74 & 381.34 & $151-719$ & 70.98 & 4 \\
\hline 5 & 1.79 & 34.42 & 5.87 & 0.72 & 146.04 & $43-218$ & 23.21 & 7 \\
\hline IG & & & & & 407.24 & & 67.56 & \\
\hline $\mathrm{G}$ & & & & & 414.75 & & 90.83 & \\
\hline \multicolumn{9}{|c|}{ Site 128-798; Japan Sea; mbsl: 900.1, slope ${ }^{\mathrm{d}}$} \\
\hline 1 & 3.33 & 3.98 & 1.11 & 6.18 & 143.79 & $76-265$ & 11.83 & 7 \\
\hline 2 & 2.88 & 5.88 & 1.24 & 5.06 & 110.2 & $98-131$ & 9.89 & 5 \\
\hline 3 & 2.66 & 5.17 & 0.97 & 4.06 & 69.77 & 49-90 & 5.69 & 4 \\
\hline 4 & 5.56 & 7.18 & 1.38 & 4.72 & 180.52 & $101-258$ & 14.27 & 7 \\
\hline 5 & 6.44 & 4.98 & 0.96 & 4.77 & 106.15 & 46-198 & 6.29 & 12 \\
\hline 6 & 2.82 & 5.09 & 1.25 & 3.53 & 58.84 & $43-74$ & 6.43 & 2 \\
\hline IG & & & & & 111.28 & & 7.94 & \\
\hline $\mathrm{G}$ & & & & & 138.02 & & 10.19 & \\
\hline
\end{tabular}


Table 1. Continued.

\begin{tabular}{|c|c|c|c|c|c|c|c|c|}
\hline MIS & Fe-bound P & Authigenic P & Detrital P & Org. P & Reac. P MAR & P MAR range & Detr. P MAR & $\mathrm{n}$ \\
\hline \multicolumn{9}{|c|}{ Site 130-806; Ontong-Java Plateau; mbsl: 2520.7, above present lysocline, basin ${ }^{\mathrm{e}}$} \\
\hline 1 & 8.26 & 5.12 & 0.41 & 1.08 & 57.96 & $37-76$ & 1.64 & 3 \\
\hline 2 & 3.11 & 6.7 & 0.49 & 0.91 & 40.56 & $38-46$ & 1.85 & 3 \\
\hline 3 & 5.24 & 6.57 & 0.46 & 1.04 & 42.41 & $33-61$ & 1.52 & 6 \\
\hline 4 & 3.46 & 7.52 & 0.44 & 1 & 27.68 & $26-30$ & 1.02 & 3 \\
\hline 5 & 3.73 & 6.43 & 0.62 & 0.68 & 33.84 & $18-58$ & 1.94 & 11 \\
\hline 6 & 1.96 & 5.38 & 0.42 & 0.65 & 143.2 & I & 7.53 & 1 \\
\hline IG & & & & & 40.03 & & 1.7 & \\
\hline $\mathrm{G}$ & & & & & 31.29 & & 3.47 & \\
\hline \multicolumn{9}{|c|}{ Site 151-907; North Atlantic Gateways; mbsl: 1800.8, low productivity, basin ${ }^{\mathrm{f}}$} \\
\hline 1 & 5.82 & 4.18 & 1.75 & 3.35 & 17.62 & $17-18$ & 2.31 & 2 \\
\hline 2 & 4.75 & 7.72 & 3.16 & 2.63 & 22.42 & $18-27$ & 4.69 & 2 \\
\hline 3 & 5.9 & 9.54 & 2.75 & 2.32 & 24.76 & $20-29$ & 3.83 & 5 \\
\hline 4 & 6.6 & 10.24 & 3.33 & 2.58 & 28.12 & $25-31$ & 4.82 & 2 \\
\hline 5 & 6.91 & 8.73 & 3.03 & 2.46 & 26.05 & $22-29$ & 4.36 & 8 \\
\hline 6 & 6.13 & 11.27 & 2.15 & 2.16 & 27.07 & $26-29$ & 2.98 & 2 \\
\hline IG & & & & & 24.49 & & 3.5 & \\
\hline $\mathrm{G}$ & & & & & 25.87 & & 4.16 & \\
\hline \multicolumn{9}{|c|}{ Site 184-1143; South China Sea; mbsl: 2772, carbonate platform, continental rise ${ }^{\mathrm{g}}$} \\
\hline 1 & 5.52 & 4.18 & 0.69 & 3.46 & 31.82 & $30-33$ & 1.67 & 5 \\
\hline 2 & 3.86 & 2.76 & 1.05 & 3.51 & 41.86 & $25-49$ & 4.34 & 5 \\
\hline 3 & 3.31 & 2.42 & 0.93 & 3.6 & 44.82 & $37-63$ & 4.47 & 21 \\
\hline 4 & 2.1 & 4.09 & 1.37 & 2.96 & 41.01 & $29-52$ & 6.14 & 9 \\
\hline 5 & 3.51 & 7.19 & 1.05 & 2.54 & 45.13 & 13-107 & 3.58 & 16 \\
\hline 6 & 3.42 & 3.73 & 0.63 & 2.31 & 15.45 & / & 1.03 & 1 \\
\hline IG & & & & & 43.39 & & 3.24 & \\
\hline $\mathrm{G}$ & & & & & 39.59 & & 3.84 & \\
\hline \multicolumn{9}{|c|}{ Site 184-1144; South China Sea; mbsl: 2037, sediment drift, continental rise ${ }^{\text {h }}$} \\
\hline 1 & 7.06 & 6.93 & 2.24 & 2.99 & 772.98 & $447-1341$ & 101.97 & 7 \\
\hline 2 & 3.58 & 6.67 & 2.49 & 2.79 & 1648.21 & 1195-1947 & 314.73 & 9 \\
\hline 3 & 4.85 & 6.67 & 3.4 & 2.67 & 1495.13 & 804-3781 & 358.24 & 22 \\
\hline 4 & 6.76 & 7.29 & 3.18 & 2.57 & 1539.53 & $975-2377$ & 294.57 & 9 \\
\hline 5 & 7.08 & 6.94 & 2.69 & 2.46 & 1195.68 & $240-1833$ & 195.17 & 13 \\
\hline 6 & 6.95 & 6.57 & 1.83 & 2.19 & 794.87 & I & 92.59 & 1 \\
\hline IG & & & & & 1282.09 & & 218.46 & \\
\hline $\mathrm{G}$ & & & & & 1551.82 & & 233.96 & \\
\hline
\end{tabular}

(hydrocarbons produced between $300^{\circ} \mathrm{C}$ and $650^{\circ} \mathrm{C}$ ), the $\mathrm{S}_{3}$ peak $\left(\mathrm{CO}_{2}\right.$ from pyrolysis of organic carbon up to $400^{\circ} \mathrm{C}$, IR-curve), and the $\mathrm{S}_{4}$ peak $\left(\mathrm{CO}_{2}\right.$ released from residual organic carbon below ca. $550^{\circ} \mathrm{C}$ during the oxidation step). All analyses were performed at the Geological Institute of the University of Neuchâtel, Switzerland. Sediments were attributed to glacial and interglacial isotopic stages characteristic of the last 150000 years, based on the oxygen stable isotope stratigraphy available for each ODP Site, and P MAR were calculated as the product of $\mathrm{P}$ concentration, dry bulk density, and sedimentation rates characteristic of each site as provided by the referred literature (Table 1). Age models, sedimentation rates and dry bulk density data were obtained from the ODP literature, i.e. both ODP Preliminary Reports and Scientific Results volumes available for each studied Leg (see Table 1 and Supplementary Material for the complete list of references). To estimate P BF, we have used the average MAR and the areal extent of the oceanographic setting to which each site belongs (Tables 1 and 2). During glacials, the areal extent of the exposed shelf has been 
Table 2. Global estimates of reactive phosphorus burial fluxes (P BF; in $10^{10}$ moles/yr). The areal extent of the exposed shelf during full glacial conditions is considered equal to $16 \times 10^{6} \mathrm{~km}^{2}$ (Meybeck and Vörösmarty, 2005). The calculated global burial fluxes are then used in the modeling, the outcomes of which are presented in Fig. 4; see text and Table 3 for details. ${ }^{a}$ : Burial fluxes for the shelf environment are calculated using an average reactive $\mathrm{P}$ concentration of $12 \mu \mathrm{mol} / \mathrm{gr}$, average sed. rates of $250 \mathrm{~mm} / \mathrm{kyr}$, and average DBD of $1 \mathrm{~g} / \mathrm{cm}^{3}$. ${ }^{\mathrm{b}}$ : Hydrothermal phosphorus input from Wheat et al. (2003).

\begin{tabular}{lcccrcc}
\hline $\begin{array}{l}\text { Oceanographic } \\
\text { settings }\end{array}$ & $\begin{array}{c}\text { Areal } \\
\text { extent }\end{array}$ & $\begin{array}{c}\text { Interglacial } \\
\text { P BF }\end{array}$ & $\begin{array}{c}\text { Glacial } \\
\text { P BF }\end{array}$ & $\Delta$ G-IG & $\begin{array}{c}\text { Interglacial } \\
\text { detrital P BF }\end{array}$ & $\begin{array}{c}\text { Glacial } \\
\text { detrital P BF }\end{array}$ \\
\hline Shelf $^{\mathrm{a}}$ & 28.9 (IG) $12.8(\mathrm{G})$ & 8.66 & 3.8 & $-56 \%$ & 2.89 & 1.28 \\
Slope (Site 798) & 26.35 & 2.92 & 3.37 & $15 \%$ & 0.23 & 0.27 \\
Rise (Sites 658, 1143, 1144) & 19.1 & 10.01 & 12.18 & $22 \%$ & 1.51 & 1.78 \\
Basin (Sites 806, 907) & 151.3 & 4.84 & 4.23 & $-12 \%$ & 0.39 & 0.58 \\
Upwelling (Sites 680, 724) $_{\text {Hydrothermal }}^{\text {b }}$ & $5.42)$ & 3.97 & 4.28 & $8 \%$ & 0.28 & 0.38 \\
TOTAL & & 2.8 & 2.8 & $0 \%$ & & \\
\hline
\end{tabular}

Table 3. Parameters used in modeling, see Fig. 4 for outcomes.

\begin{tabular}{|c|c|c|c|c|c|}
\hline Simulation & $\begin{array}{l}\text { Time } \\
(\mathrm{kyr})\end{array}$ & $\begin{array}{c}F_{\text {input }} \\
\left(10^{10} \text { moles } / y r\right)\end{array}$ & $\begin{array}{c}F_{\text {output }} \\
\left(10^{10} \text { moles } / y r\right)\end{array}$ & $\begin{array}{l}\text { Phosphate inventory } \\
\quad\left(10^{15} \text { moles }\right)\end{array}$ & Increase \\
\hline \multirow[t]{3}{*}{1} & 0 & 36.00 & 33.20 & 3.2 & \\
\hline & 100 & 29.00 & 30.66 & 3.75 & $17 \%$ \\
\hline & 120 & 36.00 & 33.20 & 3.86 & $21 \%$ \\
\hline \multirow[t]{3}{*}{2} & 0 & 33.20 & 33.20 & 3.2 & \\
\hline & 100 & 33.20 & 30.66 & 4.45 & $40 \%$ \\
\hline & 120 & 33.20 & 33.20 & 4.7 & $47 \%$ \\
\hline \multirow[t]{3}{*}{3} & 0 & 30.00 & 2 kyr aver. & 3.2 & \\
\hline & 100 & 24.10 & 2 kyr aver. & 4.56 & $43 \%$ \\
\hline & 120 & 30.00 & 2 kyr aver. & 3.86 & $21 \%$ \\
\hline
\end{tabular}

considered equal to $16 \times 10^{6} \mathrm{~km}^{2}$ (Meybeck and Vörösmarty, 2005), while only $12.8 \times 10^{6} \mathrm{~km}^{2}$, equal to $40 \%$ of the modern shelf, remained flooded. The estimated relative error for the BF is about $7-10 \%$ (calculated as the sum of the relative errors associated with each parameter included in the calculation of the burial fluxes). Because ODP does not target shallow water and shelf environments, we looked in the literature for reactive $\mathrm{P}$ data obtained using the SEDEX extraction. Data from Mississippi and Long Island Sound, Indian margin and Japan Sea were averaged and the value was used to calculate burial fluxes for the shelf environment (Ruttenberg and Berner, 1993; Babu and Nath, 2005; Cha et al., 2005) (see Table 2). To account for P burial in hydrothermal regions, we use the value proposed by Wheat and coauthors (2003), who have evaluated the importance of hydrothermal processes in scavenging P. Based on several ODP and DSDP data, they estimated a burial flux of $\mathrm{P}$ in these environments (e.g. mid-oceanic and volcanic ridges) of about $2.8 \times 10^{10}$ moles/yr (Wheat et al., 2003). We have assumed this flux to be constant over glacial-interglacial periods. We are aware that our sites are not fully representative of world oceans, since several regions, such as the Southern Ocean or the Equatorial Pacific, important in terms of productivity and $\mathrm{C}$ cycle, are not included in this study. However, the calculated interglacial BF $\left(33.2 \times 10^{10}\right.$ moles/year $)$ is in the range of independently published data and estimates between $28 \times 10^{10}$ and $36 \times 10^{10}$ moles/year (Wallmann, 2003; Ruttenberg, 2005). For this reason, we consider that our data are suitable for calculating glacial burial fluxes, which hitherto have been generally estimated only by indirect methods (Wallmann, 2003). The use of BF in our discussion avoids any overestimation of single location MAR. For instance, it is true that MAR are highest at the Peru and Oman upwelling sites (see Table 1 and Fig. 2), but BF in upwelling environments represent on average not more than $15 \%$ of the total BF. 

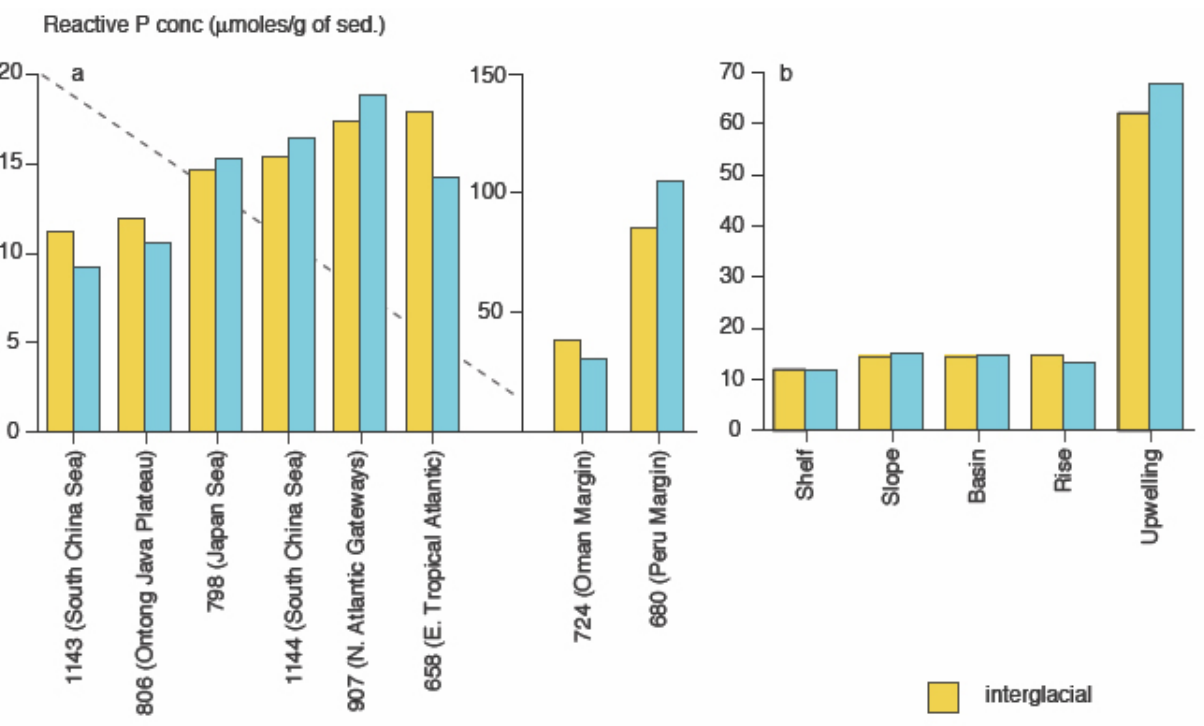

Reactive P MAR ( $\mu$ moles/cm2/kyr)
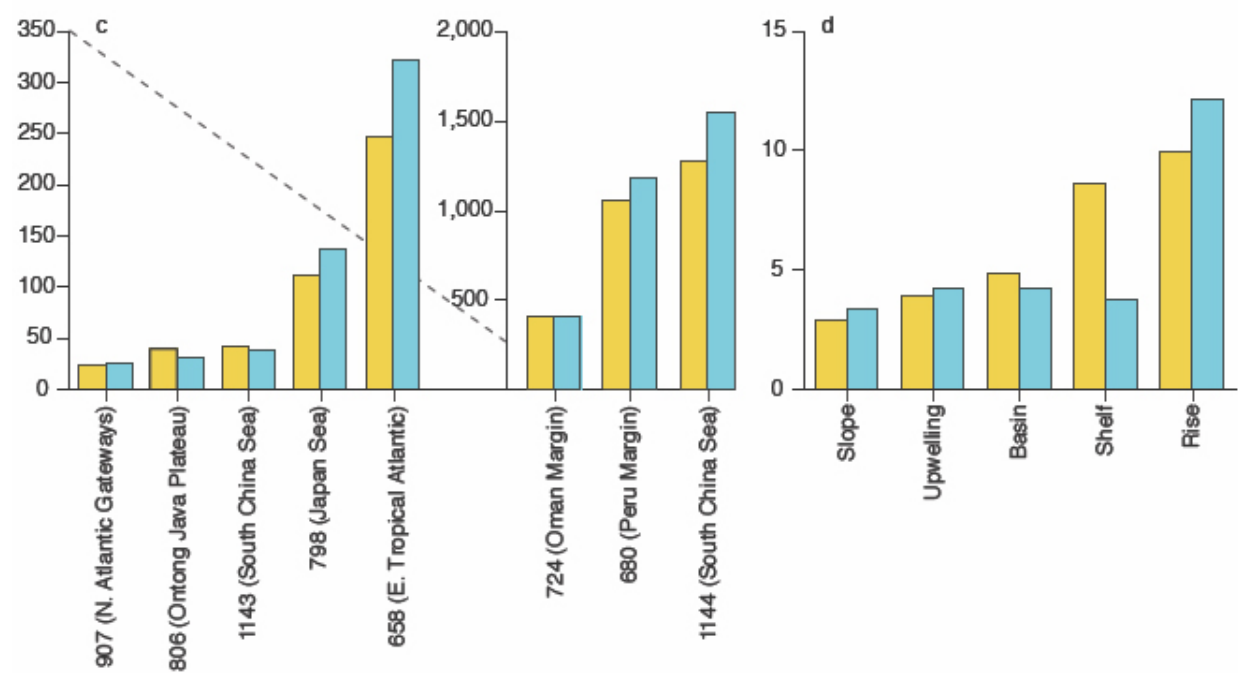

Fig. 2. Reactive P concentrations (a and b) and MAR averages (c and d) for interglacial (dark bars) and glacial (light bars) periods. Vertical scales change for ODP Sites 680 and 724 (a and c). Concentrations of reactive P range between 9 and $105 \mu \mathrm{mol} / \mathrm{g}$ of sediment. Highest concentrations are observed in sediments from the Peru margin (ODP Site 680). Reactive P MAR range between 25 and $1500 \mu \mathrm{mol} / \mathrm{cm}^{2} / \mathrm{kyr}$, and the highest values are recorded in the northern part of the South China Sea (ODP Site 1144). Average concentrations and P MAR for the different oceanographic settings are reported in panels (b) and (d).

\section{Results}

\subsection{Phosphorus and carbon data}

Authigenic $P$ represents the most important sink of reactive $P$ (represented by the sum of loosely and Fe-bound, authigenic, and organically-bound), and averages between 36 and $78 \%$ of reactive $\mathrm{P}$ (data of $\mathrm{P}$ phases concentrations are reported in the Supplementary Material). In interglacial sediments, reactive $\mathrm{P}$ concentrations fall in a relatively narrow range, between 9.5 and $18 \mu \mathrm{mol} / \mathrm{g}$ (Fig. 2), while high reactive
$\mathrm{P}$ concentrations are observed at the Peru and Oman margin sites (Table 1 and Fig. 2a). These two sites represent high productivity sites (total primary production higher than $500 \mathrm{mgC} / \mathrm{m}^{2}$ per day), where phosphorite deposition also occurs. A similar distribution for $\mathrm{P}$ concentrations is observed in glacial sediments (Fig. 2), with authigenic $\mathrm{P}$ being the most important reactive phase. Concerning variations in the sedimentary distribution of $\mathrm{P}$ phases, it is important to note here that there is no evidence of a substantial diagenetic imprint on the $\mathrm{P}$ records. At many sites organic $\mathrm{P}$ is characterized by a down-core decreasing trend, characteristic of a 
post-depositional mineralization of this phase. However, the amount of organic $\mathrm{P}$ lost is not high enough to explain the concentration changes observed in the other reactive phases, such as loosely- and Fe-bound, and authigenic P. Glacial and interglacial averages of the sedimentary $P$ phases show some differences and patterns, however only at few sites these are statistically significant (see Supplementary Material for statistical treatment of data; the statistic significance of the difference between glacial and interglacial averages of each $P$ phase at each core is also given). In fact, the distribution of $\mathrm{P}$ phases in the sediments is highly variable, both between sites and in time. In some sites, we observe lower amounts of reactive $\mathrm{P}$ during glacial times, generally attributable to a decrease in loosely- and Fe-bound $\mathrm{P}$, while authigenic $\mathrm{P}$ seems to increase. In upwelling areas, loosely- and Fe-bound $\mathrm{P}$ show lower concentrations at the beginning of interglacial stages, while in the other environments, this phase is always higher than during glacial stages (Fig. 3). Authigenic P is higher at glacial terminations and generally shows higher concentrations during interglacial stages in upwelling and rise environments. In slope and basin sites, this phase shows, on the other hand, lower values at glacial terminations and during interglacials. Organic $\mathrm{P}$ mimics organic $\mathrm{C}$ behavior and shows higher concentrations during interglacials. As expected, detrital $\mathrm{P}$ concentrations are generally higher during glacial periods. We have used organic $\mathrm{C}$ and $\mathrm{P}$ data to calculate $\mathrm{C} / \mathrm{P}$ organic and reactive molar ratios (Anderson and Delaney, 2001; see Supplementary Material for all C/P ratios data). Because of analytical problems due to high contents of carbonate and detrital material, the $\mathrm{C} / \mathrm{P}$ ratios for the two basin sites (Sites 860 and 907) are to be taken with caution. $\mathrm{C} / \mathrm{P}_{\text {org }}$ ratios approach the Redfield ratio at the top cores at all sites with the exception of the upwelling sites, where higher values are observed. At same sites (e.g. Sites 658, 798 and 1144$), C / P_{\text {org }}$ and $C / \mathrm{P}_{\text {reactive }}$ records show peak values at glacial terminations and tend to decrease during interglacial periods (e.g. Sites 724, 1143, 1144). Dictated mainly by local sedimentation rates (Filippelli, 1997), reactive P MAR change from site to site, and show more substantial variations than those shown by concentrations (Fig. 2). Interglacial and glacial reactive $\mathrm{P}$ BF show different behavior depending on the environment. $\mathrm{P}$ BF in slope and rise settings are higher during glacials, but this increase did not compensate for lower BF in shelf and basin environments, so, on a global average, $\mathrm{P}$ burial fluxes are lower for glacial intervals by about $8 \%$ (Table 2). The estimates of the oceanic replacement time of phosphorus, calculated as the ratio between the oceanic phosphate inventory (equal to $3.2 \times 10^{15}$ moles, see Delaney, 1998) and phosphorus burial fluxes, range between 9.6 and $10.4 \mathrm{kyr}$, for interglacial and glacial times, respectively. Lower P burial fluxes during glacial periods may be explained by changes in deep water characteristics (such as oxygen content, alkalinity, organic matter delivery and burial in sediments) that may have enhanced regeneration of $\mathrm{P}$ and release from sediments (Colman and Holland, 2000), or by

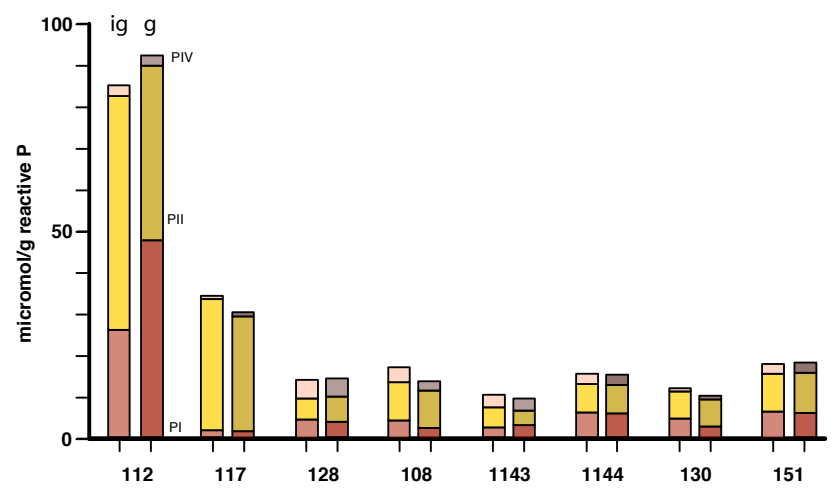

Fig. 3. Interglacial (lighter) and glacial (darker) reactive $P$ concentrations at the studied ODP Sites. PI = loosely- and Fe-bound P; $\mathrm{PII}=$ authigenic $\mathrm{P}$; and PIV = organic $\mathrm{P}$. Data, averages and statistic testing are available in the Supplementary Material.

temporal changes in P flux from the continent to the ocean. Even though our data suggest a decrease in detrital P fluxes from the continent, there is no clear evidence to suggest that glacial reactive $\mathrm{P}$ input from the continents was lower during glacial periods. In fact, global weathering rates and sedimentation rates are estimated to be similar if not higher during glacial than during interglacial times (Kump and Alley, 1994). In fact, recent studies indicate that an increased $P$ input from continents during glacial periods may also be possible (Föllmi et al., 2009). On the other hand, changes in bottom water chemistry during glacials may have lowered $\mathrm{P} \mathrm{BF}$ and, as a consequence, had an impact on the $\mathrm{P}$ cycle. Studies have suggested that during the last glacial maximum ocean waters were more stratified (Paillard and Parrenin, 2004; Jaccard et al., 2005), bottom waters were more alkaline (Sanyal et al., 1997; Paillard and Parrenin, 2004), and oxygen concentrations in bottom waters and in surface sediments were locally lower than during interglacial periods (Sirocko et al., 2000). Changes in these parameters might have a significant impact on the marine $\mathrm{P}$ cycle, in that they define the paths of organic matter degradation, redox cycling of Fe, formation of P-bearing minerals, and degree of remobilization of P during early diagenesis (Jarvis et al., 1994; Ingall and Jahnke, 1997). Additionally glacial lowering of sea level exposed large portions of the shelves (Meybeck and Vörösmarty, 2005), where extensive fluvial systems developed (Pelejero et al., 1999), and previously deposited organic and inorganic material might have been reworked and transported offshore, potentially delivering additional reactive $\mathrm{P}$ to the glacial ocean and increasing the oceanic phosphate inventory (Filippelli et al., 2007). These hypotheses are compatible with data and models; $\mathrm{Cd} / \mathrm{Ca}$ measurements in benthic foraminifera suggest that glacial deep waters were enriched in $\mathrm{PO}_{4}^{3-}$ (Boyle and Keigwin, 1987), and results of numerical models suggest the presence of a less ventilated ocean, with deep waters being enriched in $\mathrm{CO}_{2}$ and $\mathrm{PO}_{4}^{3-}$ 
(Toggweiler, 1999; Wallmann, 2003). Our data show that loosely- and $\mathrm{Fe}$-bound $\mathrm{P}$ phase present low values during glacial periods, especially at deep environments. Studies of Heinrich events in the North Atlantic have, in fact, demonstrated how this phase is sensitive to changes in circulation and oxygen content of deep waters (Tamburini et al., 2002). High values are on the other hand observed at glacial terminations and during interglacial periods, possibly indicating a more ventilated deep ocean. In a recent study based on data from a single sediment core recovered in the Mexican upwelling area, Ganeshram and co-authors (2002) also inferred a glacial decline in phosphogenesis in continental margins and upwelling areas, but dismissed the hypothesis of an increased glacial oceanic phosphate inventory, which was assumed to be not higher than $10 \%$ of its interglacial value. In fact, they suggested that the lack of $P$ deposition in shallow sites was compensated by deposition in deeper areas. They concluded that glacial increases in productivity were most likely small because of the slow and not important increase in the oceanic phosphate inventory Ganeshram et al. (2002). Our data indicate indeed a decrease in $\mathrm{P}$ burial fluxes during glacial periods, but they also show that during glacial times phosphorus burial fluxes were not higher in deep ocean sediments.

\subsection{Modeling phosphate concentration changes}

Using the estimated phosphorus burial fluxes and a simple mathematical approach, we try to understand if the differences in burial fluxes might have changed the global oceanic phosphate inventory over a full interglacial-glacial cycle (120 kyr). With this approach, we do not take into consideration other data, such as carbon fluxes, because some of the investigated ODP Sites lack detailed and accurate information with regards to carbon contents and burial rates. In this respect, our approach has a limited scope compared to geochemical models aiming at simulating changes in oceanic $\mathrm{P}$ inventory over geological time scales in response to changes in ventilation of ocean waters, productivity, and oxygen content (Wallmann, 2003; Tsandev et al., 2008). Because we consider changes in burial fluxes, we first state that changes in the phosphate inventory of the ocean over time are controlled by the difference between input and output fluxes:

$$
\frac{\delta I}{\delta t}=F_{\text {input }}-F_{\text {output }}
$$

where $I$ is the ocean phosphate inventory, $F$ is flux and $t$ is time. We calculate changes in the oceanic phosphate inventory for a time interval of $120 \mathrm{kyr}$, which represents a full interglacial-glacial cycle, using time steps of $2 \mathrm{kyr}$ (see Fig. 3), with initial full interglacial conditions set at $t=0 \mathrm{kyr}$, full glacial at $t=100 \mathrm{kyr}$, and final full interglacial at $t=120$ kyr. Integrating Eq. (1), we obtain:

$$
I(t)=I(0)+F_{\text {input }}-F_{\text {output }}
$$

where $I(t)$ at $t=0$ equals to the interglacial phosphate inventory. Not knowing the exact value of the oceanic phosphate inventory during the last interglacial (about $130 \mathrm{kyr}$ ago), and being at present in an interglacial period, we choose to set $I(0)$ to modern values $\left(3.2 \times 10^{15}\right.$ moles, see Delaney, 1998). One major problem is given by the determination and quantification of $F_{\text {input }}$, considered as the total input (dissolved and particulate) of reactive $\mathrm{P}$ from the continent, during interglacial and glacial times. Investigations on sediment traps and core top material have shown that water column particulate $\mathrm{P}$, with the exception of the detrital fraction, is actively involved in the biogeochemical cycling of $\mathrm{P}$ (Faul et al., 2005). Values for the pre-anthropogenic flux of total dissolved and particulate $\mathrm{P}$ input from the continent to the ocean are set to be about $41.2 \times 10^{10} \mathrm{moles} / \mathrm{yr}$ (Wallmann, 2003 and references therein). Knowing from our dataset the value for the detrital $\mathrm{P}$ flux into the sediments (average of $5 \times 10^{10}$ moles/yr), we obtain an estimate for the flux of reactive $\mathrm{P}$ of about $36 \times 10^{10}$ moles/yr. To evaluate interglacial values, we also test the hypotheses that the input of reactive $\mathrm{P}$ corresponds to 1 . $45 \%$ of total particulate and dissolved riverine $\mathrm{P}$ flux $\left(30 \times 10^{10} \mathrm{moles} / \mathrm{yr}\right)$, as suggested by Ruttenberg (2003), and 2. to the interglacial $F_{\text {output }}$ $\left(33.2 \times 10^{10} \mathrm{moles} / \mathrm{yr}\right)$. First, we assume $F_{\text {input }}$ to be constant in time. Then, we hypothesize that $F_{\text {input }}$ may have changed with time, as suggested by the detrital phosphorus BF, which decreases approximately of 19\% during glacial times (Table 2). We assume that this decrease is proportional to the decrease of the total input of material from the continent to the ocean. In this scenario, we consider that $F_{\text {input }}$ changes linearly with time $(t)$ between the interglacial and the glacial values, this last equaling to the $81 \%$ of the input during interglacial time. We obtain, thus,

$F_{\text {input }}=a_{\text {in }}-b_{\text {in }} t$

where $a_{\text {in }}$ is $F_{\text {input }}$ during interglacial and $b_{\text {in }}$ the rate of change (see Table 3 for all parameters). For the last $20 \mathrm{kyr}$ of the glacial-interglacial cycle, corresponding to deglaciation, $F_{\text {input }}$ changed linearly between glacial and interglacial values, following

$F_{\text {input }}=a_{\text {in }}+b_{\text {in }} t$

The last parameter intervening in the mathematical model is $F_{\text {output }}$. First, we have assumed that $\mathrm{P}$ burial fluxes change linearly between the average interglacial and glacial values, as we are interested in the average change of the oceanic phosphate inventory between the two end-members of an interglacial-glacial cycle. As discussed previously, changes in $\mathrm{P}$ burial fluxes are considered linked to the gradual change in sea level and to the transport of P-bearing matter to deeper parts of the ocean, but in this simple model, changes in sea level are only implicitly considered. So, we consider that $F_{\text {output }}$ is linearly dependent on time $(t)$

$F_{\text {output }}=a_{\text {out }}-b_{\text {out }} t$ 
where $a$ corresponds to average interglacial $\mathrm{P} \quad \mathrm{BF}$ $\left(33.20 \times 10^{10} \mathrm{moles} / \mathrm{yr}\right)$ and $b$ represents the change in output flux over time $(\Delta t=100 \mathrm{kyr})$, and is equal to $2.54 \times 10^{5} \mathrm{moles} / \mathrm{yr}^{2}$. The values of $a_{\text {output }}$ and $b_{\text {output }}$ are obtained by linear regression between the average interglacial $\left(33.20 \times 10^{10} \mathrm{moles} / \mathrm{yr}\right)$ and glacial burial fluxes $\left(30.66 \times 10^{10} \mathrm{moles} / \mathrm{yr}\right)$. For the last $20 \mathrm{kyr}, a$ and $b$ are obtained by linear regression between the average glacial and interglacial burial flux values. Second, we have calculated $2 \mathrm{kyr}$ averages of global $\mathrm{P}$ burial fluxes over the ocean, based of the data obtained from the eight studied sites. We have integrated in Eq. (2) the different estimates for $F_{\text {input }}$ and $F_{\text {output }}$ and obtained 12 distinct simulations. Some simulations predict final oceanic phosphate inventories, which are unrealistic. In most of these cases, $F_{\text {input }}$ is not balanced by the burial flux of phosphorus in the sediments, leading to an unreasonably high oceanic phosphate inventory. In few simulations, where $F_{\text {input }}$ is set to lowest values, glacial and interglacial oceanic phosphate inventory after 100 and $120 \mathrm{kyr}$, respectively, are unrealistically low. Besides the simplicity of the approach, we think that these results are also biased by our limited knowledge of reactive $\mathrm{P} F$ input. Only three simulations show results for interglacial times (120 kyr after beginning of simulation) that are coherent with the present oceanic phosphate inventory and also agree with already published geochemical models (Fig. 4; see Table 3 for model parameters). These suggest a general increase of the global ocean phosphate inventory from the beginning of the interglacial to the glacial period, which values ranging from 3.75 to $4.71 \times 10^{15}$ moles at full glacial $(t=100 \mathrm{kyr})$, while at the re-establishment of interglacial conditions values from 3.81 to $4.72 \times 10^{15}$ moles are observed. The glacial increase ranges between 17 and $47 \%$ of the initial interglacial oceanic phosphate inventory. In all three simulations, though, the final oceanic phosphate inventory is not set again to present values. Wallmann (2003), using a coupled benthic-pelagic model, estimated the effect of changing sea level, primary productivity, and oxygen concentration in bottom waters on nitrate and phosphate ocean inventories. His work shows that ocean phosphate inventory increased of approximately $40 \%$ from interglacial to glacial values. However, once interglacial conditions were re-established, the phosphate inventory did not return to the original values, because the high phosphate accumulated in the ocean during the glacial period was not completely used before the beginning of the new interglacial period (Wallmann, 2003).

\section{Discussion}

Although aware of the pure speculative character of our mathematical approach, we will compare its results with the $\mathrm{P}$ and $\mathrm{C}$ data presented here, and forward hypotheses on how $\mathrm{P} \mathrm{BF}$ and phosphate concentrations in the ocean might have changed during a glacial-interglacial cycle. Averaged over

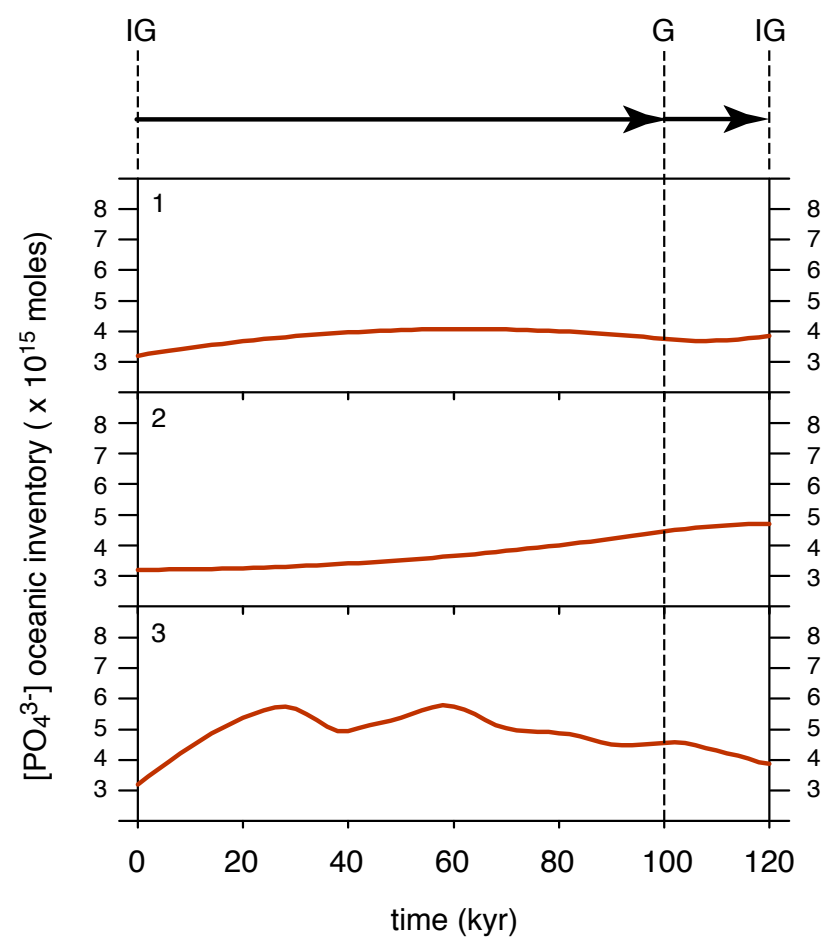

Fig. 4. Results of the interglacial-glacial simulations. The three parameters considered in the model are the initial oceanic phosphate inventory (set at interglacial values), $F_{\text {input }}$ and $F_{\text {output }}$ (see text for equations and discussion). 1: $F_{\text {input }}$ and $F_{\text {output }}$ are calculated by linear regression between interglacial and glacial average values. 2: $F_{\text {input }}$ is considered constant over the investigated period, while $F_{\text {output }}$ changes linearly. 3: $F_{\text {input }}$ is calculated by linear regression between interglacial and glacial estimates of reactive $\mathrm{P}$ input from the continent, while $F_{\text {output }}$ is represented by 2 kyr averages of oceanic $\mathrm{P}$ burial fluxes (see Table 3 for the complete list of the used parameters $) . t(0 \mathrm{kyr})=$ initial interglacial condition, IG; $t(100 \mathrm{kyr})$ $=$ glacial condition, $\mathrm{G} ; t(120 \mathrm{kyr})=$ final interglacial conditions.

the world ocean, all our data point to a decreased BF during glacial periods, as the lack of deposition on the shelves was not completely compensated by burial at deeper sites. On average loosely- and Fe-bound and organic P concentrations decrease. One possible cause for decreased phosphorus burial is the increased settling time of transported particulate $\mathrm{P}$ to the deep ocean. The longer settling time is the result of a reduction of the shelf area caused by the lowering of sea level from interglacial to glacial periods. As forwarded by Filippelli and co-authors (2007), the shift in the sinking loci of $\mathrm{P}$ from high to low sedimentation rates areas, from shallow to deep sites, would have increased the residence time of $\mathrm{P}$ in the water column, favoring the degree of recycling. If the available estimates of reactive $\mathrm{P}$ input from the continent during glacial times are not completely biased, even the small recorded change in $\mathrm{P}$ burial during glacial times, might have helped in building up phosphate in the ocean waters, increasing the global oceanic phosphate inventory. The 
increase could have ranged between 17 and $40 \%$, as indicated by our simple modeling and in agreement with previous studies (Wallmann, 2003; Tsandev et al., 2008). Ocean mixing could have provided phosphate rich waters to the the surface ocean at intermediate and low latitudes, while at high latitudes (i.e. Southern Ocean and Subarctic Pacific), phosphate most likely accumulated in deep waters because of water column stratification, with little impact on the surface water phosphate pool (Frank et al., 2000; Jaccard et al., 2005). Interglacial P burial fluxes are higher, as is indicated also by the high reactive $\mathrm{P}$ concentrations at almost all sites. At shallow sites $\mathrm{C} / \mathrm{P}$ ratios are generally lower probably indicating higher retention of $\mathrm{P}$ in the sediments (C/P reactive), or different degrees of organic matter degradation (C/P organic). At glacial termination and onset of interglacial periods, the observed peaks in several reactive $\mathrm{P}$ phases concentrations, especially at shallow sites, might testify to an increased $\mathrm{P}$ availability and retention capacity of the sediments. In fact, after sea level rise and invigoration of oceanic circulation, deep waters rich in phosphate might have been brought up to the surface on the now re-flooded shelves. The larger extension of the shelves provided the conditions for the formation of P-rich sediments, as testified by the peaks of reactive $P$ at several sites and as seen at other upwelling and shelf locations at the beginning of interglacial periods (Ganeshram et al., 2002; Tamburini et al., 2003). Alternatively, an increase in $P$ fluxes from the continents at the onset of interglacial periods, linked to the melting of glaciers and chemical weathering of moraine deposits, may have lead to the increase in reactive $\mathrm{P} B F$ in shallow water settings (Föllmi et al., 2009). Overall, the data and the depicted scenario are compatible with the Shelf-Nutrient Hypothesis (Filippelli et al., 2007) and would support the biological pump theory (Martin et al., 1991; Moore and Doney, 2007). However, recent modeling studies indicate that despite the remarkable increase in ocean phosphate inventory during glacial times, productivity and $\mathrm{CO}_{2}$ were not affected (Tsandev et al., 2008).

\section{Conclusions}

Extrapolating from a number of ODP Sites, we suggest that $\mathrm{P}$ burial fluxes were on average only $8 \%$ lower during last glacial period. However, no matter how little the difference between interglacial and glacial phosphorus burial fluxes is, and despite our knowledge of reactive $\mathrm{P}$ input from the continent is limited, ocean phosphate inventory could have changed during the last glacial-interglacial cycle. P concentrations in sediments remained homogeneous over time, but lower P BF suggest that the delivery of material from the exposed shelves to the deeper ocean and changes in chemical characteristics of deep waters from interglacial to glacial periods likely promoted the release of $\mathrm{P}$ from particulate inorganic and organic material, as proposed by other stud- ies. This might have increased phosphate concentrations of glacial waters. At the termination of glacial times and onset of the interglacial period, the re-submerged shelves may have provided locations for the burial of phosphate-rich sediments, as testified by P data. Our sediment phosphorus data and the calculation of the possible changes in oceanic phosphate inventory based on these, support several reconstructions and geochemical model outcomes targeting changes in phosphate behavior and inventory between interglacial and glacial times (Broecker, 1982; Wallmann, 2003; Filippelli et al., 2007; Slomp and Van Cappellen, 2007; Tsandev et al., 2008). The oceanographic changes associated with the transition from an interglacial to a glacial time, and the postulated changes in oceanic phosphate inventory, suggest that the oceanic $\mathrm{P}$ cycle is indeed influenced by climate variability, even on short time scales. This is also supported by the most recent estimates of $\mathrm{P}$ residence time, which are in the range of Milankovitch and sub-Milankovitch scales (Ruttenberg, 2005). Even if confined to only 8 locations and more data especially from shallow environments are needed, the $\mathrm{P}$ geochemical data presented in this study provide a valuable database to use and integrate in geochemical modeling studies and for further understand the $\mathrm{P}$ cycle and its complex link to climate.

Acknowledgements. The authors would like to thank P. Steinmann, O. Marchal, K. Wallmann and two anonymous reviewers for their highly appreciated help with modeling and for their careful review. This work also benefits from conversations with T. Adatte, S. Bernasconi, and H. Weissert. We thank ODP, the technical staff and all the involved scientists for providing the samples used for this study. This work has been sponsored by the University of Neuchâtel and the ETH Zurich, Switzerland.

Edited by: W. Kiessling

\section{References}

Anderson, L. D. and Delaney, M. L.: Sequential extraction and analysis of phosphorus in marine sediments: Streamlining of the SEDEX procedure, Limnol. Oceanogr., 45, 509-515, 2000.

Anderson, L. D. and Delaney, M. L.: Carbon to phosphorus ratios in sediments: implications for nutrient cycling, Global Biogeochem. Cy., 15, 65-79, 2001.

Babu, P. C. and Nath, N.: Processes controlling forms of phosphorus in surficial sediments from the eastern Arabian Sea impinged by varying bottom water oxygenation conditions, Deep-Sea Res. Pt. II, 52, 1965-1980, 2005.

Baturin, G. N.: Disseminated phosphorus in oceanic sediments -a review, Mar. Geol., 84, 95-104, 1988.

Bickert, T., Berger, W. H., Burcke, S., Schmidt, H., and Wefer, G.: Late Quaternary stable isotope record of benthic foraminifers: Sites 805 and 806, Ontong Java Plateau, in: Proceedings of the Ocean Drilling Program, Scientific Results, edited by: Berger, W., Kroenke, L., and Mayer, L., ODP, Ocean Drilling Program, College Station, TX, USA, 130, 411-420, 1993. 
Boyle, E. A. and Keigwin, L.: North Atlantic thermohaline circulation during the past 20000 years linked to high-latitude surface temperature, Nature, 330, 35-40, 1987.

Broecker, W. S.: Ocean chemistry during glacial time, Geochim. Cosmochim. Ac., 46, 1689-1705, 1982.

Broecker, W. S. and Peng, T.-H.: Tracers in the Sea, LamontDoherty Geological Observatory, Palisades, NY, USA, 1982.

Bühring, C., Sarnthein, M., and Party, L. S. S.: Toba ash layers in the South China Sea: evidence of contrasting wind directions during eruption ca $74 \mathrm{ka}$, Geology, 28, 275-278, 2000.

Cha, H. J., Lee, C. B., Kim, B. S., Choi, M. S., and Ruttenberg, K. C.: Early diagenetic redistribution and burial of phosphorus in the sediments of the southwestern East Sea (Japan Sea), Mar. Geol., 216, 127-143, 2005.

Colman, A. S. and Holland, H. D.: The global diagenetic flux of phosphorus from marine sediments to the oceans: redox sensitivity and the control of atmospheric oxygen levels, in: Marine authigenesis: from global to microbial, SEPM, 66, 53-75, 2000.

Delaney, M. L.: Phosphorus accumulation in marine sediments and the oceanic phosphorus cycle, Global Biogeochem. Cy., 12, 563572, 1998.

Eaton, A., Clesceri, L., and Greenberg, A. (Eds.): Standard methods for the examination of water and wastewater, 19 edn., 1995.

Espitalié, J., Deroo, G., and Marquis, F.: La pyrolise Rock-Eval et ses applications - III Partie, Rev. Inst. Fr. Pet., 41, 73-89, 1986.

Faul, K. L., Paytan, A., and Delaney, M. L.: Phosphorus distribution in sinking oceanic particulate matter, Mar. Chem., 97, 307-333, 2005.

Filippelli, G. M.: Controls on phosphorus concentration and accumulation in oceanic sediments, Mar. Geol., 139, 231-240, 1997.

Filippelli, G. M. and Delaney, M. L.: Phosphorus geochemistry of equatorial Pacific sediments, Geochim. Cosmochim. Ac., 60, 1479-1495, 1996.

Filippelli, G. M., Latimer, J. C., Murray, R. W., and Flores, J. A.: Productivity records from the Southern Ocean and the equatorial Pacific Ocean: Testing the Glacial Shelf-Nutrient Hypothesis, Deep-Sea Res. Pt. II, 54, 2443-2452, 2007.

Föllmi, K. B.: The phosphorus cycle, phosphogenesis and marine phosphate-rich deposits, Earth-Sci. Rev., 40, 55-124, 1996.

Föllmi, K. B., Cramp, A., Föllmi, K. E., Alexandrovich, J. M., Brunner, C., Burckle, L. H., Casey, M., deMenocal, P., Dunbar, R. B., Grimm, K. A., Holler, P., Ingle, J. C. J., Kheradyar, T., McEvoy, J., Nobes, D. C., Stein, R., Tada, R., von Breymann, M. T., and White, L. D.: Dark-light rhythms in the sediments of the Japan Sea: Preliminary results from Site 798, with some additional results from Sites 797 and 799, in: Proceedings of the Ocean Drilling Program, Scientific Results, edited by: Pisciotto, K., Ingle, J., von Breymann, M., Barron, J., et al., ODP, Ocean Drilling Program, College Station, TX, USA, 127-128, 559-576, 1992.

Föllmi, K. B., Hosein, R., Arn, K., and Steinmann, P.: Weathering and the mobility of phosphorus in the catchements and forefields of the Rhône and Oberaar glaciers, central Switzerland: implications for the global phosphorus cycle on glacial-interglacial timescales, Geochim. Cosmochim. Ac., 73(8), 2252-2282, 2009.

Frank, M., Gersonde, R., Rutgers van der Loeff, M., Bohrmann, G., Nümberg, C. N., Kubik, P. W., Suter, M., and Mangini, A.: Similar glacial and interglacial export bioproductivity in the Atlantic secton of the Southern Ocean: Multiproxy evidence and implications for glacial atmospheric $\mathrm{CO}_{2}$, Paleoceanography, 15 , 642-658, 2000.

Ganeshram, R. S., Pedersen, T. F., Calvert, S. E., and François, R.: Reduced nitrogen fixation in the glacial ocean inferred from changes in marine nitrogen and phosphorus inventories, Nature, 415, 156-159, 2002.

Ingall, E. and Jahnke, R.: Influence of water-column anoxia on the elemental fractionation of carbon and phosphorus during sediment diagenesis, Mar. Geol., 139, 219-229, 1997.

Ingle, J. C. J., Suyehiro, K., von Breymann, M. T., Bristow, J. S., Burkle, L. H., Charvet, J., Cragg, B. A., de Menocal, P., Dunbar, R. B., Follmi, K. B., Griffin, J. R., Grimm, K. A., Hamano, Y., Hirata, N., Holler, P., Isaacs, C. M., Kato, M., Kettler, R., Kheradyar, T., Krumsiek, K. A. O., Ling, H.-Y., Matsumoto, R., Muza, J. P., Parkes, R. J., Pouclet, A., Scott, S. D., Stein, R., and Sturz, A. A.: Site 798 Proceedings of the Ocean Drilling Program, Japan Sea, in: Proceedings of the Ocean Drilling Program, Part A: Initial Reports, ODP, Ocean Drilling Program, College Station, TX, USA, 128, 121-236, 1989.

Jaccard, S. L., Haug, G. H., Sigman, D. M., Pedersen, T. F., Thierstein, H. R., and Röhl, U.: Glacial/Interglacial changes in Subarctic North Pacific Stratification, Science, 308, 1003-1006, 2005.

Jarvis, I., Burnett, W. C., Nathan, Y., Almbaydin, F. S. M., Attia, A. K. M., Castro, L. N., Flicoteaux, R., Hilmy, M. E., Husain, V., Qutawnah, A. A., Serjani, A., and Zanin, Y. N.: Phosphorite geochemistry: state-of-art and environmental concerns, Eclogae Geol. Helv., 87, 643-700, 1994.

Kroenke, L. W., Berger, W. H., Janecek, T. R., Backman, J., Bassinot, F., Corfield, R. M., Delaney, M. L., Hagen, R. A., Jansen, E., Krisek, L. A., Lange, C., Leckie, R. M., Lind, I. L., Lyle, M. W., Mahoney, J. J., Marsters, J. C., Mayer, L. A., Mosher, D. C., Musgrave, R., Prentice, M. L., Resig, J. M., Schmidt, H., Stax, R., Storey, M., Takahashi, K., Takayama, T., Tarduno, J. A., Wilkens, R. H., Wu, G., and Krissek, L. A.: Site 806 Proceedings of the Ocean Drilling Program, Ontong Java Plateau, in: Proceedings of the Ocean Drilling Program, Part A: Initial Reports, edited by: Barbu, E. M., ODP, Ocean Drilling Program, College Station, TX, USA, 130, 291-367, 1991.

Kump, L. R. and Alley, R. B.: Global chemical weathering on glacial timescales, in: Material Fluxes on the Surface of the Earth, edited by: Usselman, T. and Hay, W., Geophysics Study Committee, National Research Council, National Academy Press, Washington D.C., USA, 46-60, 1994.

Martin, J. H., Gordon, R. M., and Fitzwater, S. E.: The case for iron, Limnol. Oceanogr., 36, 1793-1802, 1991.

McManus, J. F., Major, C. O., Flower, B. P., and Fronval, T.: Variability in sea-surface conditions in the North Atlantic-Arctic gateways during the last 140000 years, in: Proceedings of the Ocean Drilling Program, Scientific Results, edited by: Thiede, J., Myhre, A., Firth, J., Johnson, G., and Ruddiman, W., ODP, Ocean Drilling Program, College Station, TX, USA, 151, 437444, 1996.

Meybeck, M. and Vörösmarty, C.: Fluvial filtering of land-to-ocean fluxes: from natural Holocene variations to Anthropocene, C. R. Geosci., 337, 107-123, 2005.

Moore, J. K. and Doney, S. C.: Iron availability limits the ocean nitrogen inventory stabilizing feedbacks between marine denitrification and nitrogen fixation, Global Biogeochem. Cy., 21, 
GB2001, doi:10.1029/2006GB002762, 2007.

Myhre, A. M., Thiede, J., Firth, J. V., Ahagon, N., Black, K. S., Bloemendal, J., Brass, G. W., Bristow, J. F., Chow, N., Cremer, M., Davis, L., Flower, B. P., Fronval, T., Hood, J., Hull, D. M., Koc, N., Larsen, B., Lyle, M. W., McManus, J., O’Connell, S., Osterman, L. E., Rack, F. R., Sato, T., Scherer, R. P., Spiegler, D., Stein, R., Tadross, M., Wells, S., Williamson, D., Witte, B., Wolf-Welling, T., Flower, B., and Hull, D.: Site 907 Proceedings of the Ocean Drilling Program; initial reports; North AtlanticArctic gateways, in: Proceedings of the Ocean Drilling Program, Part A: Initial Reports, edited by: Marin, J. A., ODP, Ocean Drilling Program, College Station, TX, USA, 151, 57-111, 1995.

Paillard, D. and Parrenin, F.: The Antarctic ice sheet and the triggering of deglaciations, Earth Planet. Sc. Lett., 227, 263-271, 2004.

Pelejero, C., Kienast, M., Wang, L., and Grimalt, J. O.: The flooding of Sundaland during the last deglaciation: imprints in hemipelagic sediments from the southern South China Sea, Earth Planet. Sc. Lett., 171, 661-671, 1999.

Prell, W. L., Niitsuma, N., Emeis, K.-C., Al-Sulaiman, Z. K., AlTobbah, A. N. K., Anderson, D. M., Barnes, R. O., Bilak, R. A., Bloemendal, J., Bray, C. J., Busch, W. H., Clemens, S. C., de Menocal, P., Debrabant, P., Hayashida, A., Hermelin, J. O. R., Jarrard, R. D., Krissek, L. A., Kroon, D., Murray, D. W., Nigrini, C. A., Pedersen, T. F., Ricken, W., Shimmield, G. B., Spaulding, S. A., Takayama, T., ten Haven, H. L., and Weedon, G. P.: Site 724 Proceedings of the Ocean Drilling Program, Oman margin/Neogene package, in: Proceedings of the Ocean Drilling Program, Part A: Initial Reports, ODP, Ocean Drilling Program, College Station, TX, USA, 117, 385-417, 1989.

Ruddiman, W., Sarnthein, M., Baldauf, J., Backman, J., Bloemendal, J., Curry, W., Farrimond, P., Faugeres, J. C., Janacek, T., Katsura, Y., Manivit, H., Mazzullo, J., Mienert, J., Pokras, E., Raymo, M., Schultheiss, P., Stein, R., Tauxe, L., Valet, J.-P., Weaver, P., and Yasuda, H.: Site 658 Proceedings of the Ocean Drilling Program, eastern tropical Atlantic, in: Proceedings of the Ocean Drilling Program, Part A: Initial Reports, edited by: Stewart, S. K. and Rose, W. D., ODP, Ocean Drilling Program, College Station, TX, USA, 108, 105-219, 1988.

Ruttenberg, K. C.: Development of a sequential extraction method for different forms of phosphorus in marine sediments, Limnol. Oceanogr., 37, 1460-1482, 1992.

Ruttenberg, K. C.: Reassessment of the oceanic residence time of phosphorus, Chem. Geol., 107, 407-409, 1993.

Ruttenberg, K. C.: The global phosphorus cycle, in: Treatise on geochemistry, edited by: Holland, H. D. and Turekian, K. T., Elsevier, 8, 585-643, 2005.

Ruttenberg, K. C. and Berner, R. A.: Authigenic apatite formation and burial in sediments from non-upwelling, continental margin environments, Geochim. Cosmochim. Ac., 57, 991-1007, 1993.

Sanyal, A., Hemming, N. G., and Broecker, W. S.: Changes in $\mathrm{pH}$ in the eastern equatorial Pacific across stage 5-6 boundary based on boron isotopes in foraminifera, Global Biogeochem. Cy., 11, 125-133, 1997.

Sarnthein, M. and Tiedemann, R.: Toward a high-resolution stable isotope stratigraphy of the last 3.4 million years: sites 658 and 659 off Northwest Africa, in: Proceedings of the Ocean Drilling Program; Scientific Results, edited by: Ruddiman, W., Sarnthein, M., Baldauf, J., and Heath, R., ODP, Ocean Drilling Program,
College Station, TX, USA, 108, 167-185, 1989.

Schenau, S. J., Slomp, C. P., and De Lange, G. J.: Phosphogenesis and active phosphorite formation in sediments from the Arabian Sea oxygen minimum zone, Mar. Geol., 169, 1-20, 2000.

Schenau, S. J., Reichart, G. J., and De Lange, G. J.: Phosphorus burial as a function of paleoproductivity and redox conditions in Arabian Sea sediments, Geochim. Cosmochim. Ac., 69, 919931, 2005.

Sirocko, F., Garbe-Schönberg, D., and Devey, C.: Processes controlling trace elements geochemistry of Arabian Sea sediments during the last 25000 years, Global Planet. Change, 26, 217 303, 2000.

Slomp, C. P. and Van Cappellen, P.: The global marine phosphorus cycle: sensitivity to oceanic circulation, Biogeosciences, 4, 155171, 2007, http://www.biogeosciences.net/4/155/2007/.

Suess, E., von Huene, R., Emeis, K.-C., Bourgois, J., Cruzado Castaneda, J. d. C., De Wever, P., Eglinton, G., Garrison, R., Greenberg, M., Paz, E. H., Hill, P. R., Ibaraki, M., Kastner, M., Kemp, A. E. S., Kvenvolden, K. A., Langridge, R., Lindsley-Griffin, N., Marsters, J., Martini, E., McCabe, R., Ocola, L., Resig, J., Sanchez Fernandez, A. W., Schrader, H.-J., Thornburg, T. M., Wefer, G., and Yamano, M.: Site 680 Proceedings of the Ocean Drilling Program, Peru continental margin, in: Proceedings of the Ocean Drilling Program, Part A: Initial Reports, edited by: Stewart, S. K., ODP, Ocean Drilling Program, College Station, TX, USA, 112, 249-303, 1988.

Tada, R., Irino, T., and Koizumi, I.: Land-ocean linkages over orbital and millennial scales recorded in late Quaternary sediments of the Japan Sea, Paleoceanography, 14, 236-247, 1999.

Tamburini, F.: Phosphorus in marine sediments during the last 150000 years: exploring relationships between continental weathering, productivity and climate, Ph.D. thesis, electronic document, University of Neuchâtel, 2002.

Tamburini, F., Huon, S., Steinmann, P., Grousset, F. E., Adatte, T., and Föllmi, K. B.: Dysaerobic conditions during Heinrich events 4 and 5: Evidence from Phosphorus distribution in a North atlantic deep-sea core, Geochim. Cosmochim. Ac., 66, 4069-4083, 2002.

Tamburini, F., Adatte, T., Follmi, K. B., Bernasconi, S. M., and Steinmann, P.: Investigating the history of East Asian monsoon and climate during the last glacial-interglacial period (0-140 000 years): mineralogy and geochemistry of ODP Sites 1143 and 1144, South China Sea, Mar. Geol., 201, 147-168, 2003.

Tian, J., Wang, P., Cheng, X., and Li, Q.: Astronomically tuned Plio-Pleistocene benthic $\delta^{18} \mathrm{O}$ record from South China Sea and Atlantic-Pacific comparison, Earth Planet. Sc. Lett., 203(3-4), 1015-1029, 2002.

Toggweiler, J. R.: Variation of atmosphere $\mathrm{CO}_{2}$ by ventilation of the ocean's deepest water, Paleoceanography, 14, 571-588, 1999.

Tsandev, I., Clomp, C. P., and Van Cappellen, P.: Glacialinterglacial variations in marine phosphorus cycling: Implications for ocean productivity, Global Biogeochem. Cy., 22, GB4004, doi:10.1029/2007GB003054, 2008.

Van Cappellen, P. and Ingall, E. D.: Benthic phosphorus regeneration, net primary production, and ocean anoxia: a model of the coupled marine biogeochemical cycles and phosphorus, Paleoceanography, 9, 677-698, 1994.

Wallmann, K.: Feedbacks between oceanic redox states and marine productivity: a model perspective focused on benthic 
phosphorus cycling, Global Biogeochem. Cy., 17(3), 1084, doi:10.1029/2002GB001968, 2003.

Wang, P., Prell, W. L., Blum, P., Arnold, E. M., Buehring, C. J., Chen, M.-P., Clemens, S. C., Clift, P. D., Colin, C. J. G., Farrell, J. W., Higginson, M. J., Zhimin, J., Kuhnt, W., Laj, C. E., Lauer-Leredde, C., Leventhal, J. S., Anchun, L., Qingmou, L., Jian, L., McIntyre, K., Miranda, C. R., Nathan, S. A., Shyu, J.P., Solheid, P. A., Xin, S., Tamburini, F., Trentesaux, A., Wang, L., and Khunt, W.: Sites 1143-1144, Proceedings of the Ocean Drilling Program, initial reports, South China Sea; covering Leg 184 of the cruises of the drilling vessel JOIDES Resolution, in: Proceedings of the Ocean Drilling Program, Part A: Initial Reports, edited by: Nessler, S. and Green, L., ODP, Ocean Drilling Program, College Station, TX, USA, 184, p. 97, 2000.

Wefer, G., Heinze, P., and Suess, E.: Stratigraphy and sedimentation rates from oxygen isotope composition, organic carbon content, and grain-size distribution at the Peru upwelling region: Holes 680B and 686B, in: Proceedings of the Ocean Drilling Program, Scientific Results, edited by: Suess, E., von Huene, R., et al., ODP, Ocean Drilling Program, College Station, TX, USA, 112, 355-367, 1990.
Wheat, C. G., McManus, J., Mottl, M. J., and Giambalvo, E.: Oceanic phosphorus imbalance: Magnitude of the mid-ocean ridge flank hydrothermal sink, Geophys. Res. Lett., 30(17), 1895, doi:10.1029/2003GL017318, 2003.

Zahn, R. and Pedersen, T. F.: Late Pleistocene evolution of surface and mid-depth hydrography at the Oman margin: planktonic and benthic isotope records at Site 724, in: Proceedings of the Ocean Drilling Program, Scientific Results, edited by: Prell, W. and Niitsuma, N., ODP, Ocean Drilling Program, College Station, TX, USA, 117, 291-308, 1991. 